\title{
Stem cell derived basal forebrain cholinergic neurons from Alzheimer's disease patients are more susceptible to cell death
}

\author{
Lishu Duan 1* Bula J Bhattacharyya², Abdelhak Belmadani², Liuliu Pan', Richard J Miller² and John A Kessler ${ }^{1}$
}

\begin{abstract}
An early substantial loss of basal forebrain cholinergic neurons (BFCNs) is a constant feature of Alzheimer's disease (AD) and is associated with deficits in spatial learning and memory. Induced pluripotent stem cells (iPSCs) derived from patients with $A D$ as well as from normal controls could be efficiently differentiated into neurons with characteristics of BFCNs. We used BFCNs derived from iPSCs to model sporadic AD with a focus on patients with ApoE3/E4 genotypes (AD-E3/E4). BFCNs derived from AD-E3/E4 patients showed typical AD biochemical features evidenced by increased $A \beta 42 / A \beta 40$ ratios. AD-E3/E4 neurons also exhibited altered responses to treatment with $\gamma$-secretase inhibitors compared to control BFCNs or neurons derived from patients with familial AD. BFCNs from patients with AD-E3/E4 also exhibited increased vulnerability to glutamate-mediated cell death which correlated with increased intracellular free calcium upon glutamate exposure. The ability to generate BFCNs with an AD phenotype is a significant step both for understanding disease mechanisms and for facilitating screening for agents that promote synaptic integrity and neuronal survival.
\end{abstract}

Keywords: Alzheimer's disease, Human induced pluripotent stem cells, Basal forebrain cholinergic neurons, $A \beta 42 / 40$ ratio, $A \beta$ rise, Glutamate excitotoxicity, Calcium abnormalities

\section{Background}

Alzheimer's disease (AD) is a progressive debilitating neurodegenerative disorder that typically occurs in the elderly. The majority of $\mathrm{AD}$ cases are sporadic without any known genetic mutations. However polymorphism in the Apolipoprotein $E(A p o E)$ gene is a strong risk factor for $\mathrm{AD}$. Compared to individuals with an $A p o E 3 / E 3$ genotype, the presence of one copy of the $E 4$ allele increases $\mathrm{AD}$ risk by 2 to 3 fold, and two copies of $E 4$ increases risk up to 12 fold $[1,2]$.

The etiology of $\mathrm{AD}$ is poorly understood, but there are consistent pathologic features of diseased brains including senile plaques composed of $\beta$-amyloid [3,4], and neurofibrillary tangles formed by hyperphosphorylated tau [5]. $\beta$-amyloid plaques are comprised of aggregated, extracellularly deposited $A \beta$ peptides. $A \beta$ peptides are typically $39-$

\footnotetext{
* Correspondence: LishuDuan2011@u.northwestern.edu

'Departments of Neurology, Northwestern University's Feinberg School of Medicine, Feinberg School of Medicine, 303 East Chicago Avenue, Chicago, IL 60611-3008, USA

Full list of author information is available at the end of the article
}

42 amino-acids long and are generated from amyloid precursor protein (APP) by sequential $\beta$ - and $\gamma$-secretase cleavages. $A \beta 40$ is normally the major form of secreted $A \beta$ peptide recovered from cerebrospinal fluid, while $A \beta 42$ represents less than $10 \%$ [6]. However, in $\mathrm{AD}$, the more amyloidogenic A $\beta 42$ is significantly elevated and is hypothesized to be the initial and predominant species found in plaques [7]. The progressive cognitive decline of $\mathrm{AD}$ is a consequence of loss of synapses and eventually neurons in basal forebrain, cortex and hippocampus [8,9]. Basal forebrain cholinergic neurons (BFCNs) are the predominant source of cortical cholinergic input and play a central role in spatial learning and memory. AD-related tauopathies arise earliest in cholinergic neurons of the basal forebrain and loss of these neurons parallels cognitive decline $[10,11]$. For these reasons this population of neurons is an ideal target for the study of the cellular pathophysiology of AD.

Study of Alzheimer's disease has been limited in the past by the lack of availability of live neurons derived from AD patients. However induced pluripotent stem cells (iPSCs) can be derived from human skin fibroblasts

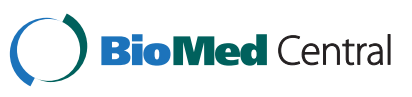


or other easily accessible tissues and can then be differentiated into neurons [12,13]. Mixed neuronal cultures derived in such a way from $\mathrm{AD}$ patients displayed some biochemical features of the disease including increased $A \beta 42 / 40$ ratios, elevated levels of $A \beta 42$ or $A \beta 40$, and increased phosphorylation of tau [14-16]. However the abnormalities in these studies were largely demonstrated for familial AD caused by genetic mutations in presenilin or $A P P$, and disease manifestations were highly variable in the limited sporadic AD lines that were examined.

We previously developed a protocol to generate a high percentage of BFCNs from human embryonic stem cells (hESCs) [17]. In this report we find that the same techniques can be used to generate BFCNs with high efficiency from iPSCs. We focused on sporadic AD with an ApoE3/E4 genotype and found that BFCNs derived from such patients display biochemical abnormalities associated with the disease and are more susceptible to both glutamate- and calcium- mediated cell death.

\section{Results}

Generation of iPSCs from human control and Alzheimer's disease fibroblasts

Age matched human fibroblasts were purchased from Coriell institute from either healthy controls or Alzheimer's disease patients with ApoE3/E4 genotypes. iPSCs were generated with a polycistronic retroviral vector encoding Klf4, Oct4, Sox2 and C-Myc (Additional file 1: Figure S1). Individual colonies were picked and expanded as separate lines. We established control iPSCs lines from the following subjects: control1, a 43-year-old female; control2, a 71-year old female; control3, a 61-year old male; an iPSCs line from WiCell (iPS-DF69-9T) was used as a fourth control. Sporadic Alzheimer's disease iPSC lines with ApoE3/E4 genotypes included: AG05810, a 79-year old female with late AD onset; AG04402, a 47-year old male with early AD onset; and AG11414, a 39-year old male with early AD onset. We also included two familial AD lines in some of our studies as comparators: AG06848, a 56-year-old female with a presenilin1 point mutation and AG07872, a 53year-old male $\mathrm{AD}$ patient with genetic mutations. A complete list of iPSCs lines we used is provided in Table 1.

All control and AD iPSCs lines showed typical human embryonic stem cell (hESC) morphology and maintained normal karyotypes during culturing (data not shown). Undifferentiated iPSCs all immunostained for the pluripotent stem cell markers Oct4, Sox2, SSEA4, andTra1-60 (Additional file 2: Figure S2A). When differentiated in vitro using embryoid body formation, both control and AD iPSCs gave rise to cell types of all three germ layers, as demonstrated by marker staining, Collagen type IV (mesoderm), Gata4 (endoderm) and Map2 (ectoderm) (Additional file 2: Figure S2B). Some lines were also tested for their ability to form teretaomas, and the tested lines were able to generate teratomas with features characteristic of mesoderm, endoderm and ectoderm (Additional file 2: Figure S2C), further confirming their pluripotent stem cell identity.

\section{Electrophysiologically active BFCNs generation from control and AD iPSCs}

Our laboratory previously reported generation from hESCs of highly enriched cultures of cells with the characteristics of BFCNs [17]. Although iPSCs are similar to hESCs, they are not identical and can have differences such as differential promoter methylation states and gene expression patterns [18]. We therefore asked if the protocol used to generate BFCNs from hESCs could be applied to iPSCs. We treated iPSCs grown on feeder free matrigel matrix with retinoic acid for 7 days and dissociated cells for neurosphere formation. Robust neurosphere formation was seen with both control and AD iPSCs. Sonic hedgehog (SHH) and FGF8 signaling are involved in patterning BFCNs precursors in the medial ganglion eminence (MGE) during the development of ventral forebrain $[19,20]$ and are required for BFCNs generation from hESCs [17]. We therefore asked if iPSCs

Table 1 List of iPSCs

\begin{tabular}{|c|c|c|c|c|c|}
\hline Name & Gender & Age taken & Figures presented & Vendor & Specification \\
\hline Control1 & Male & 61 & $1,2,3,4,5, S 4, S 5, S 6$ & Coreill & Healthy control \\
\hline Control2 & Female & 43 & $4,5,6,54$ & ATCC & Healthy control \\
\hline Control3 & Female & 71 & $4,5,54$ & Coreill & Healthy control \\
\hline Control4 & Male & $\mathrm{N} / \mathrm{A}$ & 4 & WiCell & Healthy control \\
\hline AG04402 & Male & 47 & $4,5,6, S 2, S 4, S 5$ & Coriell & AD, Early APOE3/E4 \\
\hline AG11414 & Male & 39 & $3,4,5, S 2, S 4, S 5, S 6$ & Coriell & AD, Early APOE3/E4 \\
\hline AG05810 & Female & 79 & $4,5,6,54$ & Coriell & AD, Late APOE3/E4 \\
\hline AG07872 & Male & 53 & 4 & Coriell & AD, Familial \\
\hline AG066848 & Female & 56 & 4 & Coriell & AD, PS1 (A246E) \\
\hline
\end{tabular}


responded to $\mathrm{SHH}$ and FGF8 signaling and if they differentiated accordingly into a ventral forebrain precursor phenotype. Treatment of control iPSCs-derived neurospheres with $200 \mathrm{ng} / \mathrm{ml} \mathrm{SHH}$ and $100 \mathrm{ng} / \mathrm{ml} \mathrm{FGF8}$ for 72 hours resulted in translocation of the SHH downstream effector Gli1 into the nucleus (Figure 1A).

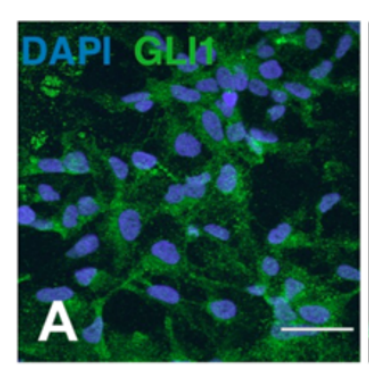

Control
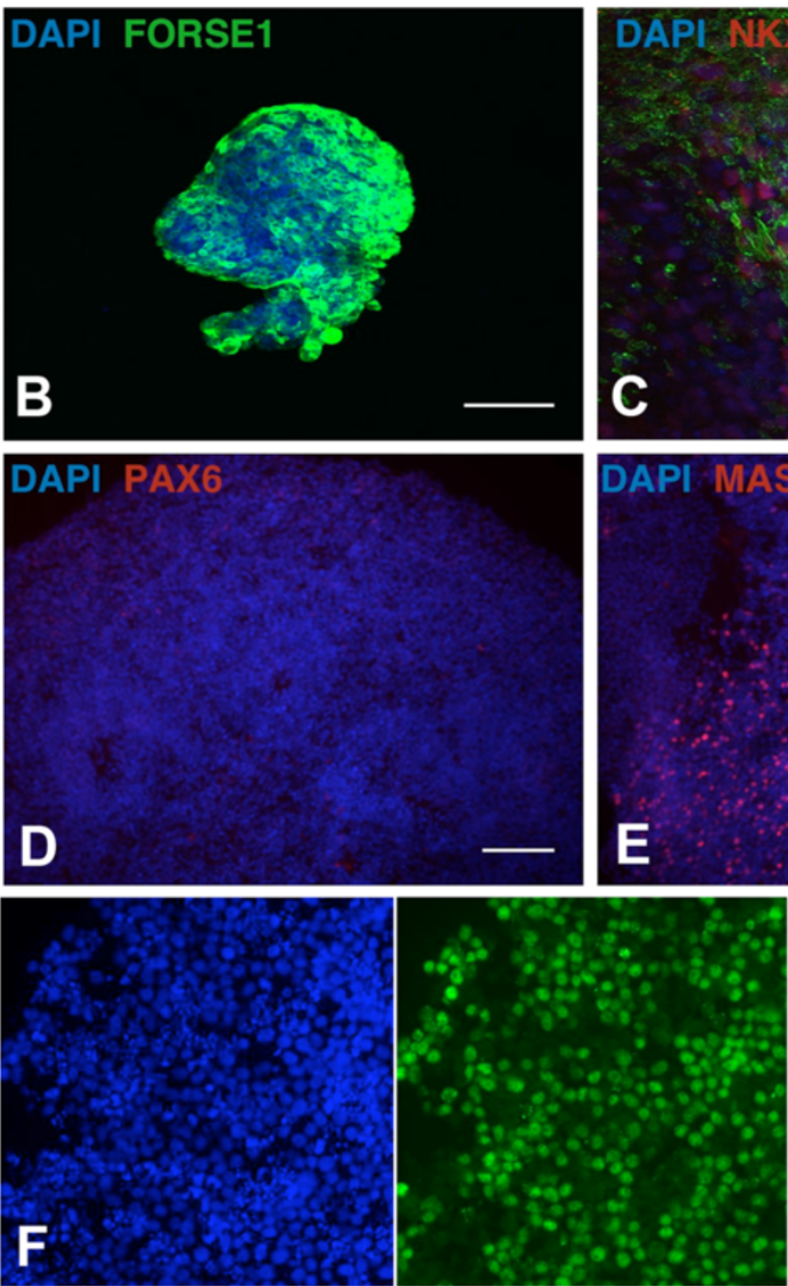

DAPI

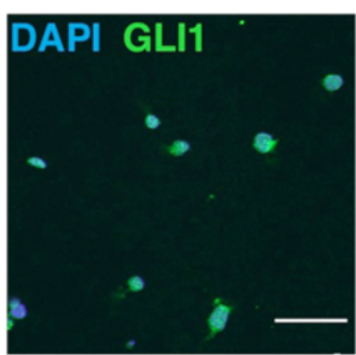

$\mathrm{SHH}$

FOXG1
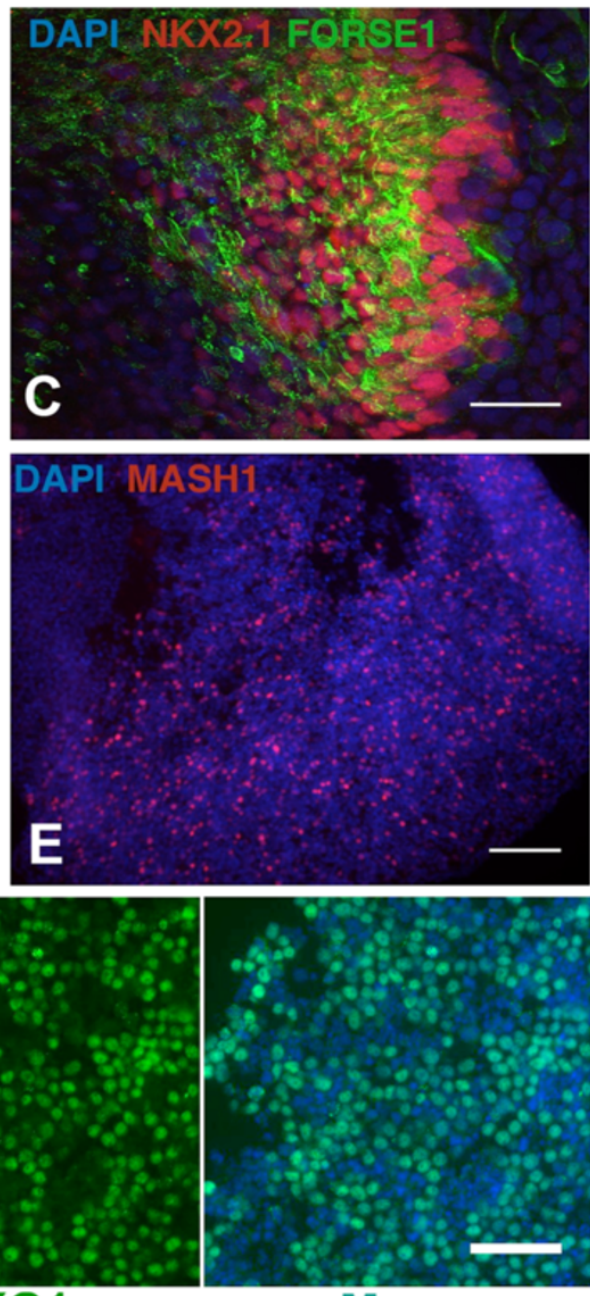

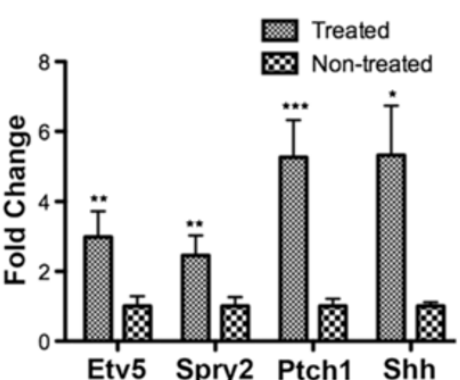

Etv5 Spry2 Ptch1 Shh 
Quantitative PCR demonstrated up-regulation of levels of the SHH downstream molecules Ptch1 and Shh [21] and the FGF8 downstream molecules Etv5 and Spry2 $[22,23]$ (Figure 1A). Thus iPSCs respond to $\mathrm{SHH}$ and FGF8 treatment by activating their appropriate downstream targets. To examine if the SHH/FGF8 treated iPSCs neurospheres were relevant progenitors for BFCNs, we immunostained the neurospheres for known MGE markers. SHH/FGF8 treated control iPSCs neurospheres expressed the forebrain marker Forse1 (Figure 1B) and the ventral markers Nkx2.1 and Mash1 (Figure 1C, E), but were negative for the dorsal marker Pax6 (Figure 1D). The cells also expressed the telencephalic marker FoxG1 (Figure 1F). Taken together, these results suggest that patterning iPSCs-derived neurospheres with SHH and FGF8 directed the cells towards a ventral forebrain progenitor phenotype, making them relevant progenitors for BFCNs.

Two transcription factors, Lhx8 and Gbx1, are crucial for BFCNs specification from committed progenitors in mice $[24,25]$, and we have previously demonstrated that Lhx8 and Gbx1 are both necessary and sufficient for BFCNs induction from hESC-derived neurospheres [17]. We therefore transiently expressed Lhx8/Gbx1-IRES-EGFP plasmid in dissociated SHH/FGF8 treated control iPSCs-derived neurospheres via nucleofection. 72 hours later, we used fluorescence-activated cell sorting (FACS) for EGFP to enrich for BFCNs progenitors which co-expressed Lhx8 and Gbx1 and then plated the cells for differentiation in neurobasal medium with nerve growth factor (NGF) (Additional file 3: Figure S3). Two weeks later, we examined the final subtype of neurons by immunostaining. More than $95 \%$ of
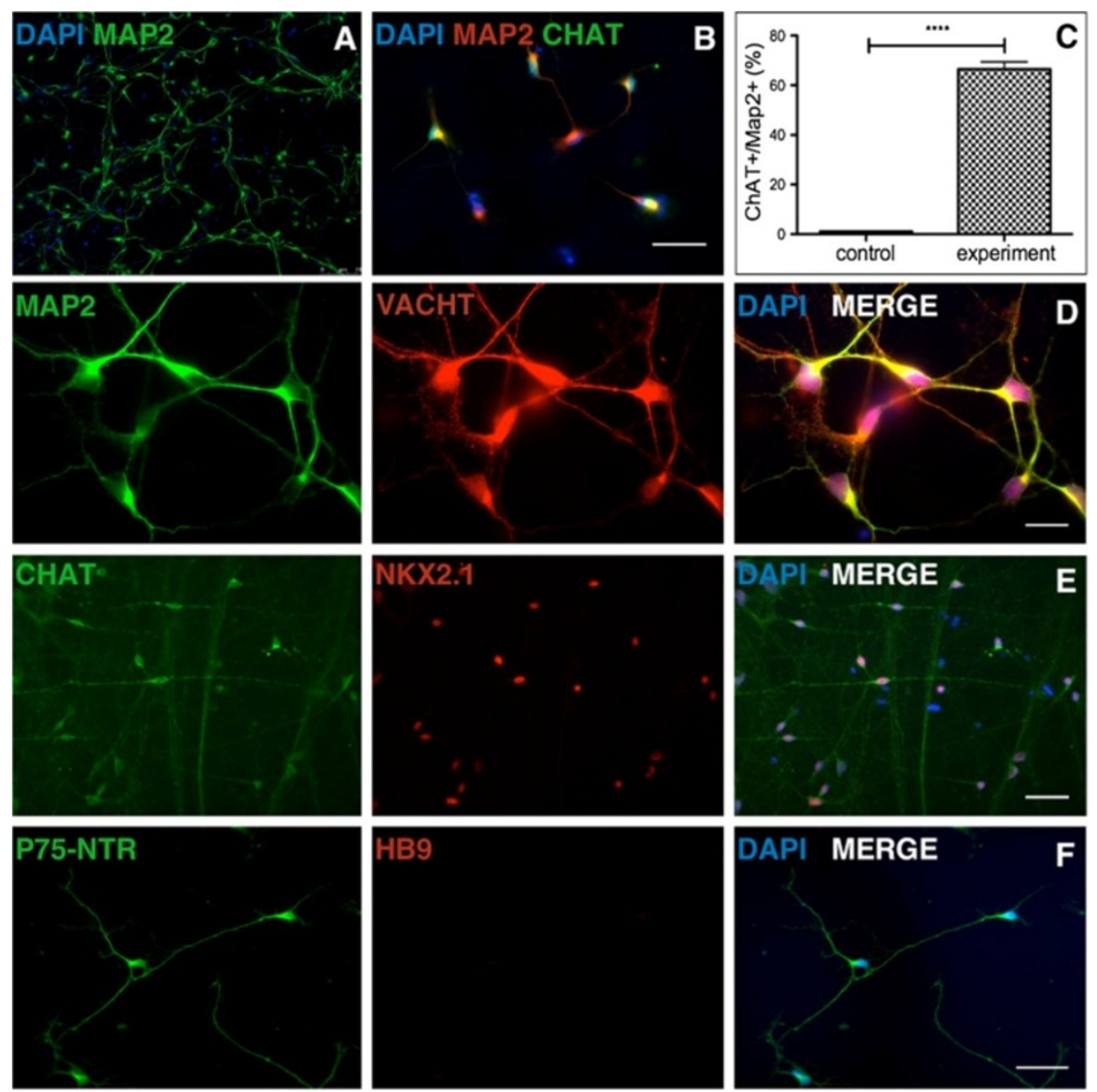

Figure 2 Generation of basal forebrain cholinergic neurons from iPSCs. (A) Over 90\% of cells derived from SHH/FGF8 treated neural progenitors (Control 1 line shown) are Map2 positive neurons. (B) ChAT positive cholinergic neurons are generated after nucleofection of SHH/ FGF8 treated neural progenitors with Lhx8/Gbx1 transcription factors. (C) Quantification of ChAT positive neurons among total Map2 positive neurons in SHH/FGF8 treated and Lhx8/Gbx1 nucleofected culture compared to non-treated, non-nucleofected control group ( $n=3$, Student's t-test, ${ }^{* * * *} p<0.0001, n$ indicates number of replicative experiments). Further confirmation of basal forebrain cholingeric identity was done by staining with (D) VAChT (E) co-expression of ChAT with Nkx2.1 (F) expression of BFCN specific marker p75-NTR but not spinal cholinergic marker HB9. Scale bars $=16 \mu \mathrm{m}$ for panel D and $85 \mu \mathrm{m}$ for other panels. Nucleus is stained with DAPI in blue. 
cells were Map-2 positive neurons (Figure 2A). Approximately $66 \pm 3 \%$ of these neurons expressed the cholinergic neuron marker choline acetyltransferase (ChAT) (Figure 2B, C) as well as another cholinergic marker, the vesicular acetylcholine transporter (VAChT) (Figure 2D). To further confirm the phenotype of these cells, we examined expression of two markers characteristic of BFCNs, the low affinity neurotrophin receptor p75 shown be to expressed by over $95 \%$ of BFCNs [26] and Nkx2.1 reported to persist in postmitotic BFCNs [27]. Immunostaining revealed co-localization of ChAT with Nkx2.1 (Figure 2E); and expression of p75, by contrast the cells did not express HB9, a cholinergic motor neuron marker (Figure 2F). There were no significant differences in the efficiency of differentiation of $\mathrm{AD}$ and control BFCNs either into ventral forebrain neural precursors or basal forebrain cholinergic neurons (Additional file 4: Figure S4). Thus we were able to differentiate both control and AD iPSCs into a BFCNs phenotype by nucleofection of specific transcription factors.

Voltage clamp recordings of 2-week old BFCNs cultures were performed to determine if the cells were electrophysiologically active in culture. Control neuron cultures showed voltage-activated currents
(Figure 3A). The inward current was blocked by tetrodotoxin (TTX) (Figure 3B), a selective voltagegated sodium channel blocker, demonstrating the presence of functional sodium channels. AD iPSCsderived neurons similarly expressed tetrodotoxinsensitive voltage-activated currents as illustrated by voltage clamp recordings in line AG11414 (Figure 3C, D). Depolarization of BFCNs with high $\mathrm{KCl}$ $(56 \mathrm{mM})$ elicited significant calcium influx in control neurons shown by calcium imaging with Fura-2 calcium dye (Figure 3E), indicating expression of voltage-gated calcium channels. AD neurons also expressed functional voltage-gated calcium channels and the amount of calcium influx through such channels upon $\mathrm{KCl}$ stimulation was not significantly different from control in the lines tested (Figure $3 F, n=3$ ). The presence of voltage-gated calcium channels in both control and AD BFCNs were further confirmed by western blot using an L-type calcium channel antibody (Additional file 5: Figure S5). Taken together, these observations indicate that we were able to use our previously established protocol to differentiate both control and AD iPSCs into highly enriched
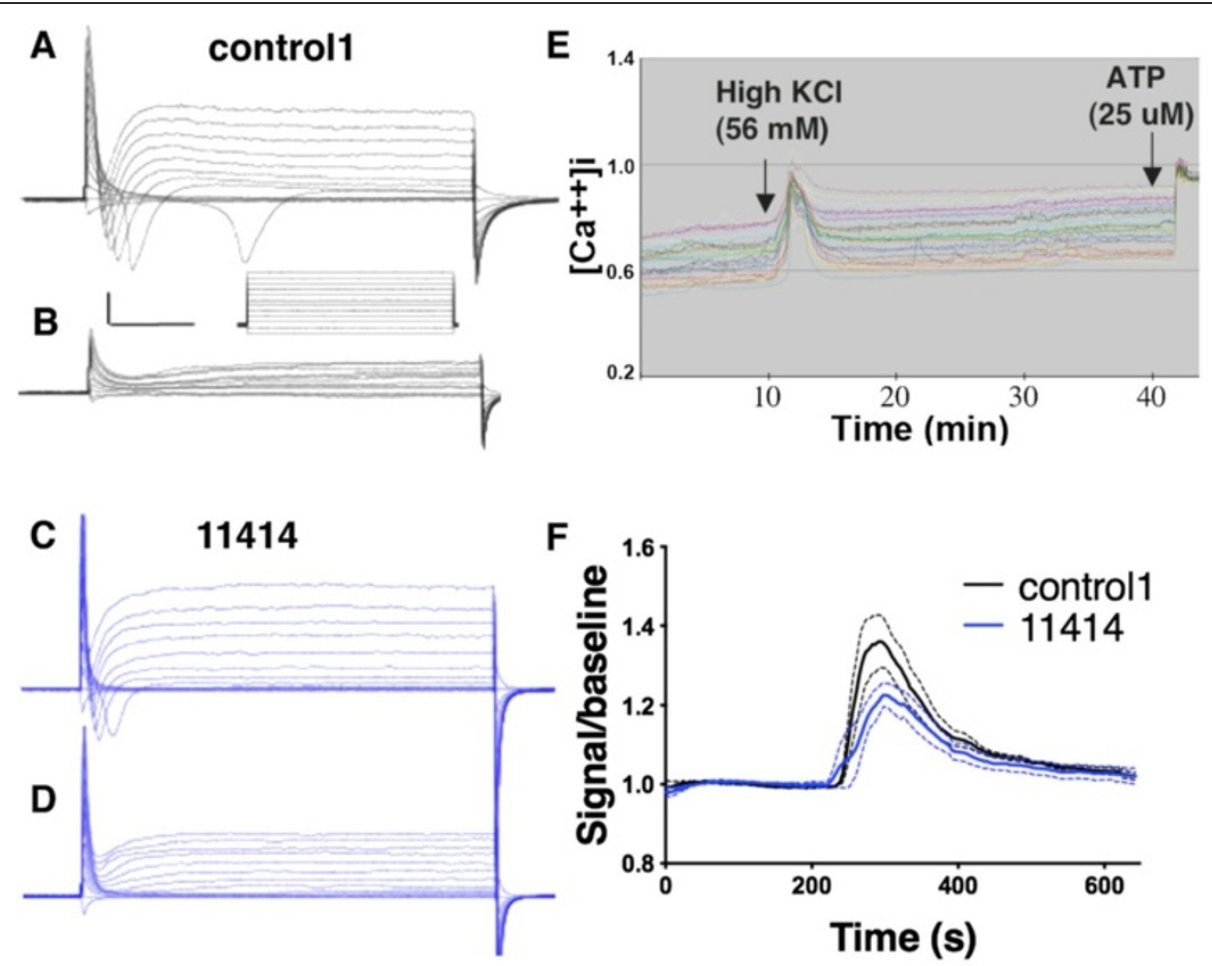

Figure 3 Control and AD iPSCs-derived BFCNs express functional voltage-gated sodium and calcium channels. Representative current traces evoked by step depolarization in the absence $\mathbf{( A , C )}$ or presence of TTX (B, D) from 2-week old control1 and ApoE3/E4 AD line AG11414 BFCNs, note the elimination of the fast-inactivating inward current in the presence of TTX. Scale bar $=1 \mathrm{nA}, 10 \mathrm{~ms}$. (E) Calcium imaging with Fura-2 showed calcium transients evoked by depolarization with $56 \mathrm{mM} \mathrm{KCl}$ (black arrow indicates time of addition) of 2-week old BFCNs. ATP was added as a control for metabolically active neurons. (F) 2-week old control and AD BFCNs were briefly exposed to $56 \mathrm{mM} \mathrm{KCl}$ and calcium influx was monitored by calcium imaging. Peak amplitude from 25 cells were averaged and normalized to baseline for each group, dashed lines indicate SEM of each data point, $n=3, n$ indicates number of replicative experiments. 
cultures of neurons that expressed characteristic BFCNs markers and that were electrophysiologically active.

\section{$A D-E 3 / E 4$ BFCNs have increased $A \beta 42 / 40$ ratios and altered responses to $\mathrm{Y}$-secretase inhibitors}

To test if our iPSCs-derived BFCNs from AD-E3/E4 patients display any disease related phenotypes, we examined $A \beta$ secretion by the cells. In addition to the normal controls we also included two familial AD cases as potential positive controls. 300,000 neurons derived from each line were cultured on 12-well plates in $1 \mathrm{ml}$ medium for 3 days and the medium was assayed simultaneously for $A \beta 42$ and $A \beta 40$ by sandwich ELISA. Cellular protein was extracted and measured by BCA protein assay to control for input cell number. ELISA results were read within the linear range of the standard curves and $A \beta$ concentrations were calculated and normalized to cellular protein level. There were no significant differences in the amount of secreted A $\beta 40$ among the lines, ranging between 200 and 300 picograms per milligram of cellular protein (data not shown). However A 342 secretion was significantly increased in several AD lines
(Figure 4A). As a result, $A \beta 42 / A \beta 40$ ratios were significantly elevated in AD-E3/E4 lines AG04402 ( 3 fold, $\mathrm{n}=4, \quad \mathrm{p}<0.0001)$ and AG11414 ( 4 fold, $\mathrm{n}=4$, $\mathrm{p}<0.0001)$ as well as in familial line AG07872 ( 2.5 fold, $\mathrm{n}=4, \mathrm{p}<0.0001)$ compared to the average of controls (Figure 4B). However, $A \beta 42 / \beta 40$ ratios were not elevated in familial line AG06848 or in AD-E3/E4 line AG05810. We then examined the effects of treatment with the $\gamma$ secretase inhibitor, compound $\mathrm{E}\left(\mathrm{IC}_{50}=300 \mathrm{pM}\right)$. At a concentration of $200 \mathrm{pM}$ the $\gamma$-secretase inhibitor reduced $\mathrm{A} \beta 40$ production as expected in the familial and control lines that were tested (Figure 4C). Surprisingly, the treatment paradoxically increased $A \beta 40$ secretion in the AD-E3/E4 line AG11414 by $67 \pm 24 \%$ (Figure $4 \mathrm{C}$ ). At a concentration of $400 \mathrm{pM}$ the inhibitor further reduced production of A $\beta 40$ in familial lines AG06848 (59 $\pm 11 \%$ reduction), AG07872 (43 $\pm 4 \%$ reduction), and control2 ( $60 \pm 19 \%$ reduction), but it increased $A \beta 40$ production from AG11414 ( $35 \pm 20 \%$ increase). To determine whether this paradoxical response occurred in other sporadic $\mathrm{AD}$ lines and with other inhibitors, we tested another $\gamma$-secretase inhibitor DAPT $\left(\mathrm{IC}_{50}=20\right.$ $n M)$ in more lines. A similar shift in $\gamma$-secretase
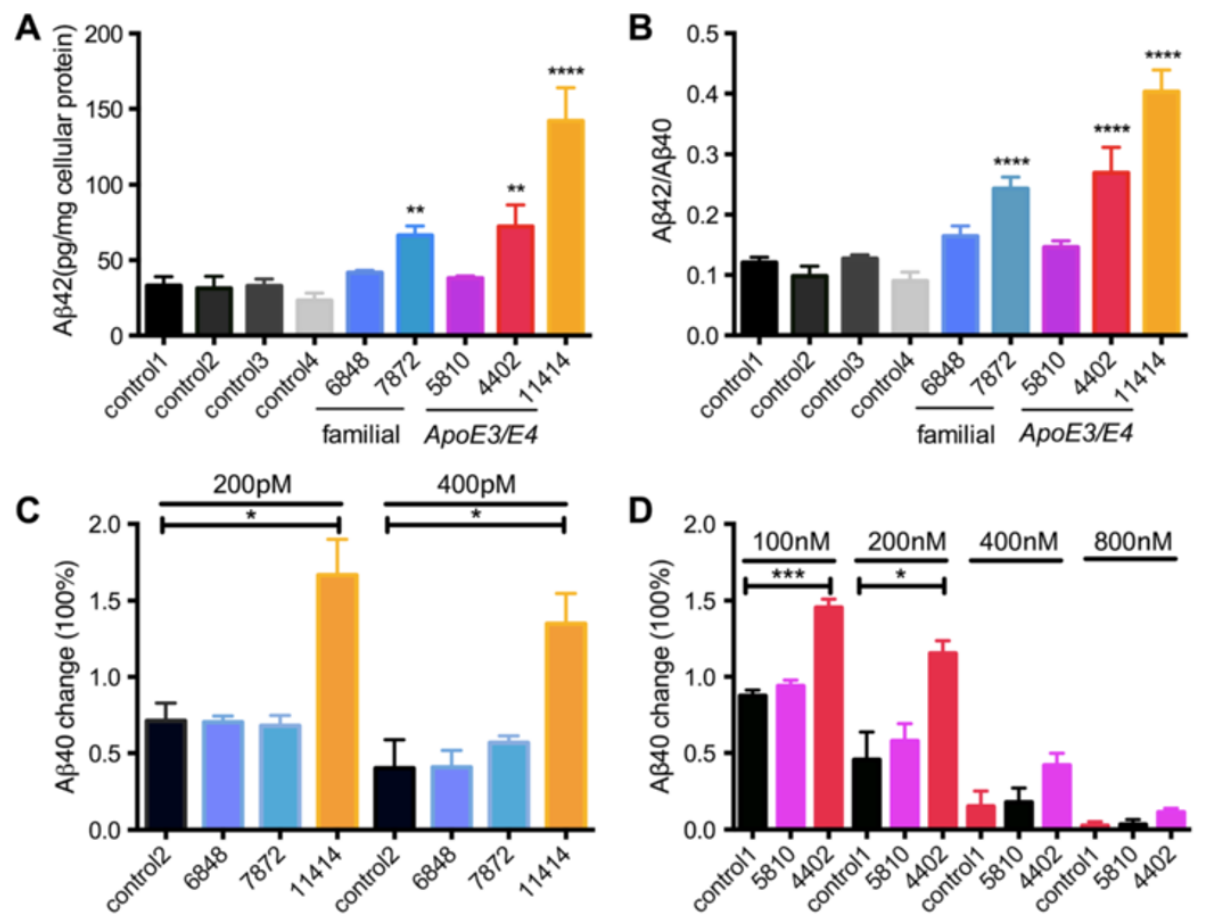

Figure 4 AD-E3/E4 BFCNs have elevated $A \beta 42 / A \beta 40$ ratios and altered responses to $\gamma$-secretase inhibitors. Medium conditioned by 300,000 neurons for 72 hours was assayed simultaneously for soluble $A \beta 40$ and $A \beta 42$ by sandwich ELISA. Levels of $A \beta$ secretion were normalized to cellular protein. (A) AB42 levels were significantly elevated in familial AD line AG07872 and ApoE3/E4 lines AG04402 and AG11414 compared to the average of controls $\left(n=4\right.$, mean \pm SEM, one-way ANOVA, $p<0.0001, F(5,36)=24.16$; Bonferroni multiple comparisons, ${ }^{* *} p<0.01$, **** $p<0.0001)$. (B) The ratios of secreted $A \beta 42$ to $A \beta 40$ were compared to the average of controls $(n=4$, mean \pm SEM, one-way ANOVA, $p<0.0001, F(5,36)=34.70$; Bonferroni multiple comparisons, $\left.{ }^{* * *} p<0.0001\right)$. (C, D) Quantification of A 440 secretion in response to different dosages of $y$-secretase inhibitor compound E (C) or DAPT (D) treatment. $\left(n=3\right.$, mean $\pm S E M$, Student's t-test, $\left.{ }^{*} p<0.5,{ }^{* * *} p<0.001\right)$, $n$ indicates number of replicative experiments from the same line. 
inhibitor potency in the AD-E3/E4 line AG04402 was observed. $A \beta 40$ secretion was increased by $45 \pm 6 \%$ and $15 \pm 6 \%$ at $100 \mathrm{nM}$ and $200 \mathrm{nM}$ DAPT concentrations respectively in AG04402. By contrast, the inhibitor reduced secretion as expected in the control line and in AG05810. At higher concentrations, (400 nM and 800 $\mathrm{nM})$ DAPT inhibited A $\beta 40$ production from all lines including AG04402 (Figure 4D). Although individual variances were observed, these findings indicate that BFCNs derived from $\mathrm{AD}$ patients with an $A p o E 3 / E 4$ genotype demonstrate $A \beta$ secretion abnormalities in vitro.

\section{AD-E3/E4 BFCNs show increased sensitivity to neurotoxic stimuli}

BFCNs degenerate early in the course of AD. Since we have a system that allows us to directly assess human BFCNs survival, we compared AD-E3/E4 and control BFCNs for susceptibility to cell death. The precise mechanisms of neuronal death in AD are still unclear, but multiple proposed mechanisms ultimately converge on disrupted calcium signaling [28]. AD mutations have been reported to deregulate calcium signaling and sensitize neurons to apoptosis [29]. To determine whether AD-E3/E4 BFCNS are more susceptible to calcium-mediated cell death, 2-week old BFCNs were treated with three different doses of the calcium ionophore, ionomycin (250 nM, $1 \mu \mathrm{M}$ or $15 \mu \mathrm{M})$ or with buffer (DSMO) for 16 hours, and a live/dead assay was performed to assess cell viability (Additional file 6: Figure S6). Neither the control nor AD groups had significant cell death after exposure to $250 \mathrm{nM}$ ionomycin (data not shown). $1 \mu \mathrm{M}$ ionomycin treatment had little effect on cell viability of control neurons, but it reduced cell viability by about $50 \%$ in AD-E3/E4 line AG11414 (Two-way ANOVA, $\mathrm{n}=3, \mathrm{p}<0.01$ ) (Figure $5 \mathrm{~A}$ ). High concentrations
$(15 \mu \mathrm{M})$ of ionomycin killed more than $70 \%$ of both control and AD neurons. Thus BFCNs derived from the AD-E3/E4 AG11414 died in response to low, normally non-lethal amounts of calcium influx.

Calcium ionophores make all membranes permeable to calcium, including plasma membranes, mitochondria and endoplasmic reticulum, which is unlikely to happen in vivo. To determine if sporadic AD-E3/E4 BFCNs are also more susceptible to more physiologically relevant neurotoxic stimuli, we examined their susceptibility to excitotoxic death in response to glutamate. 2-week old neuronal cultures were treated with either saline or $50 \mu \mathrm{M}$ L-glutamic acid for 15 minutes, washed with PBS, and incubated with culture medium for additional 24 hours. The MTT assay, which takes advantage of color conversion of the MTT dye by mitochondrial succinate dehydrogenase of living cells, was used to quantify cell viability according to the manufacturer's protocol. We included three controls and two iPSCs lines from the same sporadic AD patient AG04402 to address concerns about possible inter-line variance. The control BFCNs did not show a significant reduction in cell viability upon $50 \mu \mathrm{M}$ glutamate exposure. Late-onset ADE3/E4 line AG05810 had a 44\% reduction is cell number. Cell survival after glutamate exposure was also significantly reduced in both lines independently derived from early onset $\mathrm{AD}-\mathrm{E} 3 / \mathrm{E} 4$ line AG04402; there was a $62 \%$ reduction in cell numbers in the line labeled as 4402 and a 53\% decrease in line 4402-2 (Two-way ANOVA, $\mathrm{n}=3, \mathrm{p}<0.0001$ and $\mathrm{p}$ $<0.01$ respectively) (Figure $5 \mathrm{~B}$ ). Thus BFCNs derived from AD-E3/E4 iPSCs displayed increased susceptibility to glutamate-induced excitotoxic death. The data with two different lines from the same AD-E3/E4 patient, combined with the consistency of phenotypes in multiple control lines, suggest that the observed difference is unlikely to be
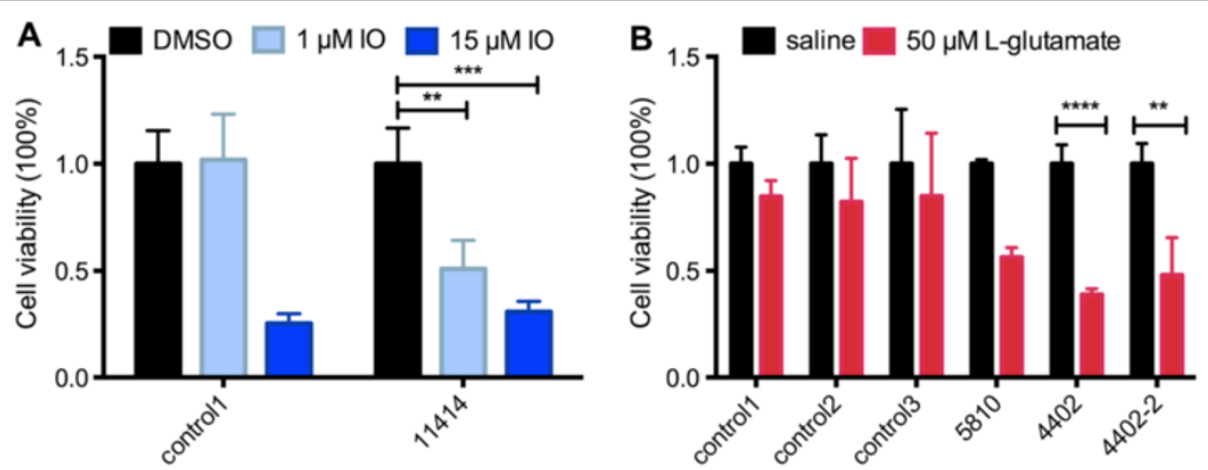

Figure 5 AD-E3/E4 BFCNs are more sensitive to ionomycin or glutamate treatment. (A) 2-week old BFCNs were treated with DMSO, $1 \mu \mathrm{M}$ or $15 \mu \mathrm{M}$ ionomycin for 16 hours, live/dead assay was performed and quantified, DMSO control is normalized to 1 . ( $n=3$, mean \pm SEM, two-way ANOVA, $p=0.0001, F(2,18)=20.53$; Bonferroni multiple comparisons, ${ }^{*} p<0.05,{ }^{* *} p<0.01,{ }^{* * *} p<0.001,{ }^{* * *} p<0.0001, n$ indicates number of replicative experiments from the same line). (B) 2-week old BFCNs were exposed to saline or $50 \mu \mathrm{M}$ glutamate for 15 minutes and cells were incubated for another 24 hours. Cell viability was quantified by MTT assay. Both sets of data are presented as percentages of living cells. ( $n=3$, mean \pm SEM, two-way ANOVA, $p<0.0001, F(1,36)=38.43$; Bonferroni multiple comparisons, ${ }^{*} p<0.05,{ }^{* *} p<0.01,{ }^{* * *} p<0.001,{ }^{* * * *} p<0.0001, n$ indicates number of replicative experiments from the same line). 
due to differences in the creation of the iPSCs, but rather reflects intrinsic genetic and disease stage associated abnormalities.

\section{AD-E3/E4 BFCNs show increased cytoplasmic calcium levels upon glutamate exposure}

Neuronal excitotoxicity is thought to be mediated by calcium dependent processes [30]. To test if calcium signaling differences were associated with the differential susceptibility of control versus AD-E3/E4 BFCNs to glutamate, we examined calcium dynamics using Fura-2 calcium imaging. 2-week old neurons were incubated with $2 \mu \mathrm{M}$ Fura-2 for 30 minutes, washed and incubated for another 30 minutes before imaging. Magnesium was excluded from all buffers to relieve the voltagedependent block of NMDA receptors. Baseline level signals were established for 10 minutes before $50 \mu \mathrm{M}$ glutamate was added briefly for 1 minute and the ratio of $340 \mathrm{~nm}$ to $380 \mathrm{~nm}$ was recorded. An enhanced calcium signal was seen strongly in both the cell bodies and in neuronal processes (Figure 6B and $\mathrm{C}$ ). The calcium transient was quantified by subtracting the baseline from the peak value and then dividing by the baseline value for each individual neuron. 20-30 neurons from each experiment were analyzed and the responses were averaged. The control lines had approximately $70 \%$ increases of free intracellular calcium when briefly exposed to glutamate. By contrast, AG05810 neurons had an increase of over $90 \%$, and AG04402 had about $110 \%$ increase in intracellular calcium levels (Figure 6A). The calcium transient was significantly higher in AD-E3/E4 lines AG05810 and AG04402 compared to the average of calcium transient in controls (One-way ANOVA, $n=3$, $\mathrm{p}<0.01$ and $\mathrm{p}<0.0001$ respectively). We also measured resting free calcium concentrations and found no statistically significant differences among the lines examined. Control neurons had free cytosolic calcium concentrations ranging between 50-80 nM, whereas concentrations for AG05810 were between 90-120 nM, and for AG04402 between 108-162 nM. These observations suggest that the increased sensitivity of AD-E3/E4 neurons to glutamate toxicity may reflect elevated cytoplasmic calcium levels upon stimulation.

\section{Discussion}

The ability to generate BFCNs with an $\mathrm{AD}$ phenotype is a significant step both for understanding disease mechanisms and for facilitating screening for agents that promote synaptic integrity and neuronal survival. Generation of relatively pure subpopulations of any type of neurons from iPSCs is difficult, and differentiation of BFCNs required a detailed protocol that was first established for the differentiation of hESCs [17]. Some approaches for the differentiation of hESCs and iPSCs are inefficient for generating BFCNs [31], and we used an approach that included retinoic acid followed by specific factors to induce a forebrain phenotype (SHH and FGF8) and nuclefection with two transcription factors (Lhx8 and Gbx1) that specify the BFCNs phenotype. Although retinoic acid (RA) may have some caudalizing effects, its use for generating forebrain precursors is well established [32,33]. SHH and FGF8 pretreated neural progenitors immunostained for the ventral marker Nkx2.1 and forebrain specific marker Forse1 [34], confirming the presence of a ventral forebrain progenitor population. The cells also expressed the forebrain marker FoxG1 which is initially detected in the cytoplasm [17] followed by translocation to the nucleus (Figure 1) as the cells begin to differentiate. Finally the cells expressed all of the known markers of the BFCNs phenotype and were electrically excitable. Although the protocol involved directed differentiation of the iPSCs, it is likely that the very high final purity of the cultures of BFCNs partially reflected selection due to early AraC treatment to eliminate proliferating cells and later NGF treatment to promote survival of BFCNs. These cultures should be useful not only for studying disease mechanisms but also for drug screening. For example, the glutamate excitotoxicity assay with MTT reagent (Figure 5) provides a direct readout for neuronal

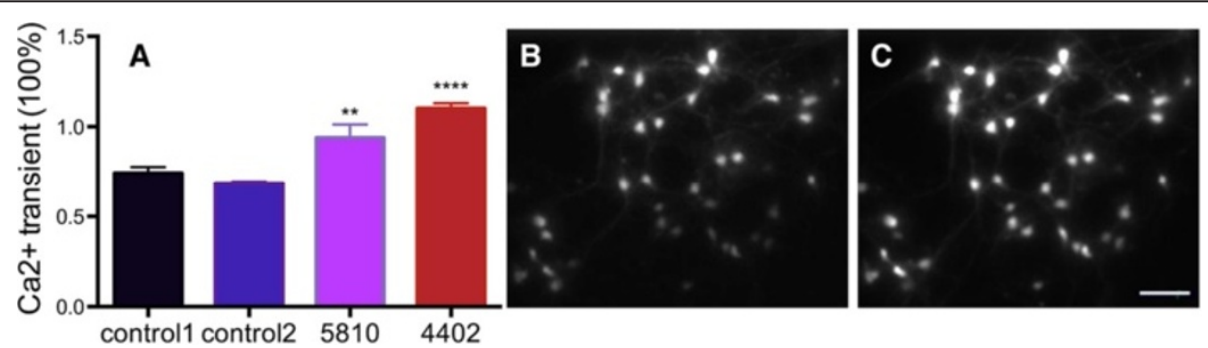

Figure 6 AD-E3/E4 BFCNs have increased cytoplasmic calcium levels upon glutamate stimulation. 2-week old neurons were briefly exposed to $50 \mu \mathrm{M}$ glutamate and responses were recorded by calcium imaging and measured by ratio of signals at $340 \mathrm{~nm} / 380 \mathrm{~nm}$. Baseline and peak amplitude is measured for each individual cell and cytosolic free calcium levels were calculated as (peak amplitude-baseline)/baseline. (A) Averages of calcium transient of 20-30 cells per experiment were calculated and compared to the average of controls ( $n=4$, mean \pm SEM, ANOVA, $p=0,0005, F(3,12)=19.55$; Bonferroni multiple comparisons, ${ }^{* *} p<0.01$, $\left.{ }^{* * * *} p<0.001\right)$, $n$ indicates number of replicative experiments from the same line. Representative images of imaged cells at $340 \mathrm{~nm}$ (B) and $380 \mathrm{~nm}$ (C) are shown. Scale bar $=85 \mu \mathrm{m}$. 
death, so that scaling the cultures to a 96 or 384-well format would provide a method for high-throughput screening for drugs that promote BFCNs survival.

There have been at least three prior studies that utilized iPSCs to study AD, but all examined heterogeneous mixtures of differentiated cells [14-16]. None of those studies examined cells from AD-E3/E4 patients, but they did examine cells from a few cases of sporadic $\mathrm{AD}$ and found great inconsistency in the phenotypes in vitro. Israel et al. reported increased A 340 secretion in one sporadic line $(A p o E 3 / E 3)$ but not the other [15]. Kondo et al. found that only one of the two sporadic cases (genotype not known) had neuronal $A \beta$ oligomer accumulation [16]. Some of the variability in those studies may reflect the heterogeneous, uncharacterized phenotypes of the differentiated cells that were examined. However heterogeneity was also observed in our study that focused on BFCNs. Although the findings with control cultures were remarkably consistent and reproducible across the four control lines used in our study, there were differences among the AD-E3/E4 lines. The AG11414 (ApoE3/E4) and AG04402 (ApoE3/E4) lines both differed significantly from controls in terms elevation of A $\beta 42 / A \beta 40$ ratios, a paradoxical response to $\gamma$-secretase inhibitors, and increased sensitivity to glutamate induced toxicity. However the AG05810 (ApoE3/E4) line did not differ significantly from the controls in these respects. The reasons for these disparate findings are not yet clear, but there are a number of possibilities. The ages of onset of disease for AG11414 (35 y.o.) and AG04402 (47 y.o. and possibly earlier) were substantially younger than for AG05810 (79 y.o.), so the difference might reflect differences between early onset versus late onset disease. It is also possible that the lines produce different amounts of ApoE4 protein. It is well recognized that the ApoE4 allele accelerates the onset of $\mathrm{AD}$ [35], and the late onset for AG05810 suggests less of an effect of the ApoE4 allele. We attempted to find out if there was differential ApoE4 protein expression compared to ApoE3 protein level among these lines by western blot using a commercially available ApoE4 specific antibody. Unfortunately the antibody was not specific and recognized ApoE3 protein as well. Inter-line variance could also account for some of the differences since we used retrovirus to generate our iPSCs, and genome integration could lead to clonal heterogeneity and potential functional diversity [36]. However we tested this by examining two different independently derived lines from the same patient and found no significant differences. Coupled with the findings by other investigators, our observations suggest that it is likely patient specific factors rather than differences in reprogramming among lines account for the observed phenotypes.

As a major risk factor in sporadic AD, the ApoE4 allele is associated with earlier onset and increased amyloid plaques in AD [37-39]. Animal studies demonstrated an isoform-dependent $(A p o E 4>A p o E 3>A p o E 2)$ effect on A $\beta$ deposition [40,41]. ApoE4 also induced neuronal A 342 accumulation in target replacement ApoE4 mice [42]. Since astrocytes are the primary sources of secreted ApoE in mice, and have been shown to bind and degrade amyloid deposits $[43,44]$, the above effects are thought to be primarily mediated by astroctyes. However our cultures contained no detectable astrocytes, and almost all of the cells expressed neuronal traits. Thus the effects of the ApoE4 allele in this study were not mediated by astrocytes. Neurons also express ApoE [45,46], and our data suggest that neuronal ApoE4 increases secretion of $A \beta 42$, the more fibrillar form that is more likely to aggregate and act as the core for amyloid plaques. In addition, we found an interesting shift of $\gamma$ secretase inhibitor potency in ApoE3/E4 AD neurons. Low concentrations of $\gamma$-secretase inhibitors significantly increased $\mathrm{A} \beta$ secretion from ApoE3/E4 neurons, in contrast to the predicted reduction of $A \beta$ seen in control and familial AD lines. Such an $A \beta$ rise at sub-threshold concentrations of $\gamma$-secretase inhibitors has been described in cell culture [47,48] and in vivo in human [49]. The underlying biochemical mechanism is not fully understood, but it is thought to be a direct $\gamma$-secretase effect [50,51]. Our finding that $A p o E$ also plays a role in this process is important since it suggests that therapeutic strategies that focus on secretase inhibition should control for the presence of the ApoE4 allele.

Excitotoxicity is involved both in acute cell death after CNS injuries and in the neuronal death that is part of AD. Human ApoE4 carriers have poorer recovery after head trauma or stroke [52,53] with severe neurodegeneration [54]. Some studies of transgenic mice that overexpress ApoE3 or ApoE4 suggested a protective role of ApoE3 against excitotoxicity compared to ApoE4 $[55,56]$ whereas other studies revealed no differences $[57,58]$. The controversy could be due to cellular source of ApoE. Buttinit et al. showed that neuron-specific expression of ApoE4 promotes excitotoxic cortical neuron death, whereas ApoE4 expressed by astrocytes was as neuroprotective as ApoE3 [59,60]. Our findings that $\mathrm{AD}-\mathrm{E} 3 / \mathrm{E} 4 \mathrm{BFCNs}$ are more susceptible to glutamate induced excitotoxic death are consistent with the suggestion that neuronal ApoE4 sensitizes neurons to excitotoxicity.

The increased vulnerability of $\mathrm{AD}-\mathrm{E} 3 / \mathrm{E} 4 \mathrm{BFCNs}$ to glutamate-mediated cell death correlated with increased intracellular free calcium upon glutamate exposure. Recombinant truncated or full-length ApoE protein elicited rapid elevation of intracellular calcium and induced rodent cortical or hippocampal neuron death [61,62]. ApoE dose-dependently increased cytosolic free calcium concentration in the order of E4 > E3 > E2 [63]. Disruption of calcium homeostasis mediated the neurotoxic 
effect of ApoE4 in transgenic mice [64]. Glutamate induced calcium elevation could result from calcium influx through NMDA receptors, metabotropic glutamate receptors, activation of voltage-sensitive calcium channels (VSCCs), or mobilization of calcium from intracellular calcium stores [65]. We found calcium influx through VSCCs did not differ significantly between one control and ApoE3/E4 line, consistent with previous findings of a lack of contribution by VSCCs to calcium mediated excitotoxicity [66,67]. Alternatively, abnormalities in the cellular calcium buffering system could also result in sustained intracellular calcium elevations.

\section{Conclusions}

In this study we modeled sporadic Alzheimer's disease with an $A p o E 3 / E 4$ genotype using human iPSCs that we established from age-matched control and AD-E3/E4 fibroblasts. We then differentiated the iPSCs into BFCNs to enable us to study the disease process in an identified, disease relevant population of human neurons. Using these iPSC-derived BFCNs, we found that AD-E3/E4 neurons had increased $A \beta 42 / A \beta 40$ ratios, a typical biochemical feature of $\mathrm{AD}$, similar to familial presenilin mutation lines $[14,16]$. However we found that lower doses of $\gamma$-secretase inhibitors surprisingly increased $A \beta$ secretion by $\mathrm{AD}-\mathrm{E} 3 / \mathrm{E} 4 \mathrm{BFCNs}$ whereas they reduced $\mathrm{A} \beta$ secretion by control and familial AD neurons as expected. AD-E3/E4 BFCNs also exhibited increased vulnerability to normally non-lethal concentrations of calcium ionophore or L-glutamate. The excitotoxicity caused by glutamate exposure correlated with increased cytosolic free calcium in the AD-E3/E4 BFCNs upon stimulation. In summary, iPSCs-derived BFCNs from patients with AD and an $A p o E 3 / E 4$ genotype display biochemical features of the disease including an increased ratio of $A \beta 42 / 40$ and increased susceptibility to cell death in response to calcium influx or exposure to glutamate. The ability to generate BFCNs with an $\mathrm{AD}$ phenotype is a significant step both for understanding disease mechanisms and for facilitating high throughput screening for agents that promote BFCNs survival.

\section{Methods}

\section{Reprogramming and cell culture}

Human age-matched control and Alzheimer's disease fibroblasts were purchased from the Coriell Cell Repositories and ATCC. Fibroblast cultures were maintained in DMEM, 15\% FBS (Fetal Bovine Serum). Fibroblasts were infected with Oct4-Klf4-Sox2-cMyc retrovirus for two rounds and split onto 75,000 cells/ml gamma-irradiated feeder cells on day 6. Medium was switched to hESC (human Embryonic Stem Cell) medium with DMEM/ F12, 20\% KSR (Knock-out Serum Replacement), $0.1 \mathrm{mM}$ non-essential amino acids, $2 \mathrm{mM}$ L-glutamine, $100 \mu \mathrm{M}$ $\beta$-mercaptoethanol, $10 \mathrm{ng} / \mathrm{ml}$ bFGF. Medium was changed every other day until colonies were picked up around day 20 and then changed daily.

\section{Teratoma assay and karyotyping}

All animal procedures were performed in accordance with the Public Service Policy on Human Care and Use of Laboratory Animals and all procedures were approved by the Northwestern University Institutional Animal Care and Use Committee. iPSCs were harvested as aggregates in hESC medium. Cells were injected subcutaneously through an 18-gauze needle into hind limbs of NOD-SCID mice. After 6-8 weeks, mice were euthanized and teratomas were excised, sectioned and analyzed by H\&E staining. iPSCs were plated in T-25 cell culture flasks and karyotyped by Children's Hospital, Oakland using standard $\mathrm{G}$ banding.

\section{Differentiation of iPSCs}

The protocol for generating BFCNs from iPSCs was adapted from our previously described protocol for hESCs [17]. Briefly, iPSCs were split onto matrigel plates in feeder cell conditioned medium supplemented with $10 \mathrm{ng} / \mathrm{ml} \mathrm{bFGF}$ and $10 \mu \mathrm{M}$ RA. After 7 days, cells were harvested in hESC medium without bFGF to allow neurosphere formation. Individual neurospheres were then picked into neurosphere medium (DMEM/F12, $0.1 \mathrm{mM}$ non-essential amino acids, $1 \times \mathrm{N} 2$ supplement, $100 \mu \mathrm{M}$ $\beta$-mercaptoethanol, $8 \mu \mathrm{g} / \mathrm{ml}$ heparin, $20 \mathrm{ng} / \mathrm{ml} \mathrm{bFGF}, 20$ $\mathrm{ng} / \mathrm{ml} \mathrm{EGF)} \mathrm{for} \mathrm{another} 4$ days. $100 \mathrm{ng} / \mathrm{ml}$ FGF8 and $200 \mathrm{ng} / \mathrm{ml} \mathrm{SHH}$ were added for 72 hours at which point neurospheres were dissociated and nucleofected with 4 $\mu$ Lhx8/Gbx1-IRES-GFP overexpression plasmid (for control, GFP plasmid was used). 48-72 hours later, cells were fac-sorted for GFP and plated in neurobasal medium with $1 \times \mathrm{B}-27$ supplement, $2 \mathrm{mM}$ glutamax, 2 mM glutamine, $20 \mathrm{ng} / \mathrm{ml}$ bFGF, 100 ng/ml NGF. Cytosine arabinoside was added from day 5 to day 10 at a concentration of $2.4 \mu \mathrm{M}$ to eliminate proliferation of contaminating non-neuronal cells.

\section{Retrovirus production}

The four human reprogramming factors were cloned into a single retroviral vector linked by $2 \mathrm{~A}$ sequences: pMXsOct4-p2A-Klf4-t2A-Sox2-e2A-cMyc (pMXs-OKSM). 293T cells were co-transfected with pMXs-OKSM, pCMV-VSVG and pCMV-gag/pol. Supernatants from day 2 and 3 were used to directly infect human fibroblasts in the presence of $5 \mathrm{ng} / \mathrm{ml}$ polybrene.

\section{Quantitative PCR (Q-PCR)}

RNA was extracted with an RNAequeous-Micro kit (Ambion). A total of 500 ng RNA was used for cDNA synthesis with the Thermoscript system (Invitrogen). 
$1 \mu \mathrm{l}$ of cDNA was mixed with SYBR green master mix (Applied Biosystems) and the PCR reaction was carried out in a Realplex ${ }^{2}$ Mastercycler (Eppendorf) using the following cycling parameters: $95^{\circ} \mathrm{C} 15 \mathrm{~s}, 60^{\circ} \mathrm{C} 60 \mathrm{~s}$ for 40 cycles. Melting curves were generated to confirm the presence of one single product.

\section{ELISA and western blot}

BFCNs were conditioned in neuron medium (see above) for 72 hours. Human $A \beta 40$ and A $\beta 42$ ELISA (Invitrogen) were carried out simultaneously according to the manufacturer's instructions with the conditioned medium. Cellular protein was harvested with M-PER protein extraction reagent with 1:500 Halt protease inhibitor cocktail (Thermo Scientific). Protein concentration was determined by BCA assay. For western blot analyses, protein samples were separated by SDS-PAGE on $4-20 \%$ Tris-glycine gradient gels (Invitrogen), and then transferred onto PDF (polyvinylidene difluoride) membranes (Millipore). Membranes were blocked with $5 \%$ milk and then incubated with primary antibodies overnight at $4^{\circ} \mathrm{C}$. HRP (Horseradish peroxidase)-conjugated secondary antibodies and $\mathrm{ECl}$ substrate (Thermo Scientific) were used for detection. Primary antibodies included: Anti-Cav1.2 (1:200, Neuromab).

\section{Neurotoxicity assays}

Neurons were treated with DMSO, $250 \mathrm{nM}, 1 \mu \mathrm{M}$ or 15 $\mu \mathrm{M}$ ionomycin for 16 hours and Live/Dead Viability/Cytotoxicity assays (Invitrogen) were performed. Cells were incubated in $2 \mu \mathrm{M}$ calcein and $4 \mu \mathrm{M}$ ethidium homodimer-1 for 30 minutes at room temperature and then immediately mounted and imaged using Zeiss microscopy. For the glutamate excitotoxicity assay, $50 \mu \mathrm{M}$ glutamate or saline dissolved in $2 \mathrm{mM}$ calcium buffer was added to 2-week neuron cultures for 15 minutes and washed twice with PBS before adding culture medium back in for another 24 hours. MTT assay from Promega was performed to determine cell viability according to manufactures' instructions.

\section{Immunocytochemistry}

Cells were fixed in 4\% PFA for 15 minutes followed by two $1 x$ PBS washes. Cells were blocked by $10 \%$ bovine serum in $1 x P B S$ at room temperature for 1 hour. Primary antibodies were applied for overnight at $4^{\circ} \mathrm{C}$ in $1 \mathrm{xPBS}$ containing $1 \%$ BSA and $0.25 \%$ Triton-X-100. Following three washes, alexa fluor conjugated secondary antibodies (1:1000, invitrogen) together with DAPI (1:2000) were added for 1 hour. After three more washes, coverslips were mounted with Prolong Gold antifade reagent (Invitrogen) and imaged. Primaries antibodies used were: Oct4 (1:1000, Santa Cruz), Sox2 (1:1000, Millipore), Ssea4 (1:500, Chemicon), Tra1-60 (1:500, Chemicon), Collagen type IV (1:500, Abcam), Gata4 (1:1000, Santa Cruz), Map2 (1:1000, Abcam), Gli1 (1:500,
Santa Cruz), Forse1 (1:300, DSHB), Nkx2.1 (1:500, Abcam), Pax6 (1:1000, DHSB), Mash1 (1:1000, BD Pharmingen), p75-NTR (1:1000, Abcam), VAChT (1:1000, SYSY), HB9 (1:1000, Abcam) and ChAT (1:600, Aves Labs).

\section{Calcium imaging}

2-week old neurons grown on PDL-coated glass coverslips were incubated with $2 \mu \mathrm{M}$ calcium-sensitive dye Fura-2 (Invitrogen) in calcium buffer for 30 mins and washed three times afterwards. Neurons were incubated for an additional 30 mins before imaging. Coverslips were mounted onto a chamber and placed on the stage of a laser confocal microscope. A $20 \times$ objective was used and the imaging was done at room temperature. Signals were collected at $3 \mathrm{~s}$ intervals from wavelengths $340 \mathrm{~nm}$ and $380 \mathrm{~nm}$ and the ratio of $340 \mathrm{~nm} / 380 \mathrm{~nm}$ was recorded. Recordings were allowed to go for 10-15 minutes to establish baseline. $56 \mathrm{mM} \mathrm{KCl}$ or $50 \mu \mathrm{M}$ glutamate were added for $1 \mathrm{~min}$ to elicit calcium influx. For measurement of cytosolic free cacium, $10 \mu \mathrm{M}$ ionomycin was added to zero calcium buffer to deplete intracellular calcium stores and to $20 \mathrm{mM}$ calcium buffer to get a maximal calcium level. Imaging buffers were adjusted to PH value of 7.2-7.4 and osmolality of 300-310. Detailed description of buffers are listed below: Calcium buffer: $125 \mathrm{mM} \mathrm{NaCl}, 3 \mathrm{mM} \mathrm{KCl}, 2 \mathrm{mM} \mathrm{CaCl} 2,25 \mathrm{mM}$ glucose, $10 \mathrm{mM}$ Hepes; Zero calcium buffer: $125 \mathrm{mM}$ $\mathrm{NaCl}, 3 \mathrm{mM} \mathrm{KCl}, 25 \mathrm{mM}$ glucose, $10 \mathrm{mM}$ Hepes, 10 mM EDTA; High calcium buffer: $100 \mathrm{mM} \mathrm{NaCl}, 3 \mathrm{mM}$ $\mathrm{KCl}, 25 \mathrm{mM}$ glucose, $10 \mathrm{mM}$ Hepes, $20 \mathrm{mM} \mathrm{CaCl} 2$.

\section{Electrophysiology}

Cultured neurons were incubated for $15 \mathrm{~min}$ at $37^{\circ} \mathrm{C}$ in oxygenated standard artificial CSF [ACSF] containing [in mM]: $130 \mathrm{NaCl}, 24 \mathrm{NaHCO}, 3.5 \mathrm{KCl}, 1.25 \mathrm{NaH} 2 \mathrm{PO} 4,1.5$ $\mathrm{CaCl} 2,1 \mathrm{MgSO} 4$, and 10 glucose, saturated with 95\% O2 and $5 \% \mathrm{CO} 2$ at $\mathrm{pH} 7.4$ and then transferred to the recording chamber in oxygenated standard ACSF. Whole cell patch clamp recordings were performed and observed with the aid of microscope [BX-50WI; Olympus] and visualized with a chilled charge-coupled device video camera [DageMTI] with a 40x water-immersion differential interference contrast objective. For whole cell voltage clamp recordings, patch electrodes with a resistance of 5-7 M were pulled from borosilicate capillaries [World Precision Instruments; PG52165-glass]. Patch pipettes were filled with a solution of [in $\mathrm{mM}$ ] $150 \mathrm{KCl}, 10$ HEPES, 4 Mg2ATP, $0.5 \mathrm{NaGTP}$, and 10 phosphocreatine. The $\mathrm{pH}$ was adjusted to 7.3 with $\mathrm{KOH}$. Whole-cell voltage clamped recordings were obtained from neurons using an Axopatch 200B patch-clamp amplifier [Molecular Devices] and the data were captured with pClamp 9.0 software [Molecular Devices]. Voltagedependent $\mathrm{Na}$ currents was recorded under voltage clamp conditions and blocked by bath application of Tetrodotoxin 
(TTX; $2 \mu \mathrm{M}$, Tocris Bioscience; R\&D Systems, Inc. MN). Data analysis. Data were filtered at $2 \mathrm{kHz}$ and digitized at $10 \mathrm{kHz}$ using a Digidata 1322A analog-to-digital board. Analysis was performed using the pClamp 9.0 [Molecular Devices].

\section{Statistics}

GraphPad software was used for statistical analyses. Student's t-test or ANOVA with the Bonferroni post test was used to generate $P$ values.

\section{Additional files}

Additional file 1: Figure S1. Polycistronic reprogramming vector map and primer sequences. (A) Reprogramming factors in the order of Oct4, Klf4, Sox2 and c-Myc were cloned into the MMLV-based retroviral backbone pMXs linked by viral 2A sequences, (B) Oct4 and Klf4, Sox2 and c-Myc were cloned using recombinant $P C R$ and the resulting two fragments were ligated via Xbal restriction site. Primers used are listed as shown.

Additional file 2: Figure S2. Induced pluripotent stem cell characterization. (A) Undifferentiated IPSC colonies stained positive for the pluripotent stem cell markers, Oct4, Sox2 (red), Ssea4 and Tra1-60 (green). Nuclear staining with DAPI is in blue. Scale bar $=85 \mu \mathrm{m}$. (control 2 line shown). (B) Following embryonic body differentiation, iPSCs gave rise to cell types positive for Map2 (green, ectoderm), Gata4 (red, endoderm) and Collagen type IV (green, mesoderm). Scale bar $=85 \mu \mathrm{m}$. (AD-E3/E4 line 4402 shown). (C) iPSCs formed teratomas when injected into mice. H\&E staining revealed characteristic morphologies of all three germ layers. Scale bar $=313 \mu \mathrm{m}$. (AD-E3/E4 line 11414 shown).

Additional file 3: Figure S3. Flow cytometry sorting for Lhx8/Gbx1/ EGFP plasmid nucleofected neural progenitor cells. Representative dot plots of flow cytometry sorting for Lhx8/Gbx1/EGFP nucleofected neura progenitor cells. (A) Dots (cells) within region R1 were live cells, this portion of cells were further sorted for GFP. (B) Dots within region R3 were GFP positive cells, indicating cells had successfully taken up the plasmid with Lhx8 and Gbx1 genes in it. GFP positive cells were sorted and plated for further experiments.

Additional file 4: Figure S4. Basal forebrain cholinergic neuron generation from AD iPSCS. (A) AD-E3/E4 line 11414 neurosphere sections after SHH and FGF8 treatment stained positive for forebrain marker FoxG1 (green) and ventral marker Nkx2.1 (red). (B) Representative confocal image of neurons generated from AD-E3/E4 line 11414 stained with neuronal marker Map2 (red) and basal forebrain cholinergic marker p75-NTR (green). Nuclear staining with DAPI is in blue. Scale bar $=85 \mu \mathrm{m}$. (C) Quantification and comparison of generation efficiency of ventral forebrain precursors, represented by the ratios of Nkx2.1, Mash1 and FoxG1 positive cells to total DAPI positive cells respectively. (D) Quantification and comparison of neuron generation efficiency, represented by the ratios of Map2 positive cells to total DAPI positive cells; and final basal forebrain cholinergic neuron purity counted as the ratio of ChAT positive neurons to Map2 positive total neurons. There are no statistically significant differences among control and AD lines in the ability of generating ventral forebrain precursors or basal forebrain cholinergic neurons $(n=3$, mean \pm SEM, two-way ANOVA, $p=0.9665$ and $p=0.4701$ respectively).

Additional file 5: Figure S5. Control and AD BFCNs express L-type voltage gated calcium channel. Western blot analysis for expression of voltage gated calcium channel by BFCNs in lines control1, 11414 and 4402-1. An anti-Cav1.2 monoclonal antibody was used to detect the a subunit of voltage gated calcium channel at around $240 \mathrm{kD}$ (upper panel). GAPDH was also probed for loading control (lower panel).

Additional file 6: Figure S6. Live/dead assay for ionomycin induced neuronal toxicity. 2-week old BFCNs from either AD (A) or control (B) lines were treated with DMSO, $1 \mu \mathrm{M}$ or $15 \mu \mathrm{M}$ ionomycin for 16 hours, live/dead assay was performed. Live cells were stained with green and counted.

\section{Abbreviations}

iPSCs: Induced Pluripotent Stem Cells; hESCs: Human Embryonic Stem Cells; BFCNs: Basal Forebrain Cholinergic Neurons; VSCC: Voltage-sensitve Calcium Channels; SHH: Sonic Hedgehog; FGF8: Fibroblast Growth Factor 8;

MGE: Medial Ganglion Eminence; NGF: Nerve Growth Factor; ChAT: Choline Acetyltransferase; VAChT: Vesicular Acetylcholine Transferase; ApoE: Apolipoprotein E.

\section{Competing interests}

The authors declare that they have no competing interests.

\section{Authors' contributions}

LD: conception and design, collection and assembly of data, data analysis and interpretation, manuscript writing; BB: collection and assembly of data, data analysis and interpretation; $\mathrm{AB}$ : collection and assembly of data, data analysis and interpretation; LP: collection and assembly of data; RM: conception and design, data analysis and interpretation, final approval of manuscript; JK: conception and design, financial support, administrative support, data analysis and interpretation, manuscript writing, final approval of manuscript.

\section{Acknowledgements}

We thank Dr. Kitamura from University of Tokyo for kindly providing us the pMXs vector and Plat-E virus packaging cell line. Ljuba Lyass from Stem Cell Core Facility of Northwestern University for help with cell culturing. Paul Mehl and Jeffery Nelson from Flow Cytometry Core Facility of Northwestern University for help with fac-sorting. And we thank Chian-yu Peng, Lixin Kan and Dilyan Dryanovski from Northwestern University for suggestions and inputs with experiments. This research if supported by NIH grants: R01 NS 20778 and R01 NS 20013.

\section{Author details}

'Departments of Neurology, Northwestern University's Feinberg School of Medicine, Feinberg School of Medicine, 303 East Chicago Avenue, Chicago, IL 60611-3008, USA. ${ }^{2}$ Molecular Pharmacology and Biological Chemistry, University's Feinberg School of Medicine, 303 East Chicago Avenue, Chicago, IL 60611-3008, USA.

Received: 4 July 2013 Accepted: 3 January 2014

Published: 8 January 2014

\section{References}

1. Roses AD: Apolipoprotein E alleles as risk factors in Alzheimer's disease. Annu Rev Med 1996, 47:387-400.

2. Bertram L, Tanzi RE: Genome-wide association studies in Alzheimer's disease. Hum Mol Genet 2009, 18:R137-R145.

3. Tomlinson BE, Blessed G, Roth M: Observations on the brains of demented old people. J Neurol Sci 1970, 11:205-242.

4. Masters $\mathrm{CL}$, Simms G, Weinman NA, Multhaup G, McDonald BL, Beyreuther K: Amyloid plaque core protein in Alzheimer disease and Down syndrome. Proc Natl Acad Sci USA 1985, 82:4245-4249.

5. Hardy J: The relationship between amyloid and tau. J Mol Neurosci 2003, 20:203-206.

6. Seubert P, Vigo-Pelfrey C, Esch F, Lee M, Dovey H, Davis D, Sinha S, Schlossmacher M, Whaley J, Swindlehurst C, et al: Isolation and quantification of soluble Alzheimer's beta-peptide from biological fluids. Nature 1992, 359:325-327.

7. Iwatsubo T, Odaka A, Suzuki N, Mizusawa H, Nukina N, Ihara Y: Visualization of $A$ beta $42(43)$ and $A$ beta 40 in senile plaques with end-specific $A$ beta monoclonals: evidence that an initially deposited species is A beta 42(43). Neuron 1994, 13:45-53.

8. Whitehouse PJ, Price DL, Struble RG, Clark AW, Coyle JT, Delon MR: Alzheimer's disease and senile dementia: loss of neurons in the basal forebrain. Science 1982, 215:1237-1239.

9. West MJ, Coleman PD, Flood DG, Troncoso JC: Differences in the pattern of hippocampal neuronal loss in normal ageing and Alzheimer's disease. Lancet 1994, 344:769-772.

10. Mesulam M: The cholinergic lesion of Alzheimer's disease: pivotal factor or side show? Learn Mem 2004, 11:43-49.

11. Mufson EJ, Ma SY, Dills J, Cochran EJ, Leurgans S, Wuu J, Bennett DA, Jaffar S, Gilmor ML, Levey Al, Kordower JH: Loss of basal forebrain P75(NTR) 
immunoreactivity in subjects with mild cognitive impairment and Alzheimer's disease. J Comp Neurol 2002, 443:136-153.

12. Takahashi K, Tanabe K, Ohnuki M, Narita M, Ichisaka T, Tomoda K, Yamanaka S: Induction of pluripotent stem cells from adult human fibroblasts by defined factors. Cell 2007, 131:861-872.

13. Yu J, Vodyanik MA, Smuga-Otto K, Antosiewicz-Bourget J, Frane JL, Tian S, Nie J, Jonsdottir GA, Ruotti V, Stewart R, et al: Induced pluripotent stem cell lines derived from human somatic cells. Science 2007, 318:1917-1920.

14. Yagi T, Ito D, Okada Y, Akamatsu W, Nihei Y, Yoshizaki T, Yamanaka S, Okano $\mathrm{H}$, Suzuki N: Modeling familial Alzheimer's disease with induced pluripotent stem cells. Hum Mol Genet 2011, 20:4530-4539.

15. Israel MA, Yuan SH, Bardy C, Reyna SM, Mu Y, Herrera C, Hefferan MP, Van Gorp S, Nazor KL, Boscolo FS, et al: Probing sporadic and familial Alzheimer's disease using induced pluripotent stem cells. Nature 2012, 482:216-220.

16. Kondo T, Asai M, Tsukita K, Kutoku Y, Ohsawa $Y$, Sunada $Y$, Imamura K, Egawa N, Yahata N, Okita K, et al: Modeling Alzheimer's disease with iPSCs reveals stress phenotypes associated with intracellular Abeta and differential drug responsiveness. Cell Stem Cell 2013, 12:487-496.

17. Bissonnette CJ, Lyass L, Bhattacharyya BJ, Belmadani A, Miller RJ, Kessler JA The controlled generation of functional basal forebrain cholinergic neurons from human embryonic stem cells. Stem Cells 2011, 29:802-811.

18. Chin MH, Mason MJ, Xie W, Volinia S, Singer M, Peterson C, Ambartsumyan G, Aimiuwu O, Richter L, Zhang J, et al: Induced pluripotent stem cells and embryonic stem cells are distinguished by gene expression signatures. Cell Stem Cell 2009, 5:111-123.

19. Tucker ES, Segall S, Gopalakrishna D, Wu Y, Vernon M, Polleux F, Lamantia AS: Molecular specification and patterning of progenitor cells in the lateral and medial ganglionic eminences. J Neurosci 2008, 28:9504-9518.

20. Schambra UB, Sulik KK, Petrusz P, Lauder JM: Ontogeny of cholinergic neurons in the mouse forebrain. J Comp Neurol 1989, 288:101-122.

21. Katoh $Y$, Katoh M: Hedgehog signaling pathway and gastrointestinal stem cell signaling network (review). Int J Mol Med 2006, 18:1019-1023.

22. Zhang Z, Verheyden JM, Hassell JA, Sun X: FGF-regulated Etv genes are essential for repressing Shh expression in mouse limb buds. Dev Cell 2009, 16:607-613.

23. Faedo A, Borello $U$, Rubenstein $\mathrm{J}$ : Repression of Fgf signaling by sprouty $1-2$ regulates cortical patterning in two distinct regions and times. J Neurosci 2010, 30:4015-4023.

24. Zhao Y, Marin O, Hermesz E, Powell A, Flames N, Palkovits M, Rubenstein JL, Westphal H: The LIM-homeobox gene Lhx8 is required for the development of many cholinergic neurons in the mouse forebrain. Proc Natl Acad Sci USA 2003, 100:9005-9010.

25. Fragkouli A, Hearn C, Errington M, Cooke S, Grigoriou M, Bliss T, Stylianopoulou F, Pachnis V: Loss of forebrain cholinergic neurons and impairment in spatial learning and memory in LHX7-deficient mice. Eur J Neurosci 2005, 21:2923-2938.

26. Mufson EJ, Ginsberg SD, Ikonomovic MD, DeKosky ST: Human cholinergic basal forebrain: chemoanatomy and neurologic dysfunction. J Chem Neuroanat 2003, 26:233-242

27. Magno L, Catanzariti V, Nitsch R, Krude H, Naumann T: Ongoing expression of Nkx2.1 in the postnatal mouse forebrain: potential for understanding NKX2.1 haploinsufficiency in humans? Brain Res 2009, 1304:164-186.

28. Mattson MP, Chan SL: Neuronal and glial calcium signaling in Alzheimer's disease. Cell Calcium 2003, 34:385-397.

29. Corona C, Pensalfini A, Frazzini V, Sensi SL: New therapeutic targets in Alzheimer's disease: brain deregulation of calcium and zinc. Cell Death Dis 2011, 2:e176.

30. Sattler R, Tymianski M: Molecular mechanisms of calcium-dependent excitotoxicity. J Mol Med 2000, 78:3-13.

31. Liu Y, Weick JP, Liu H, Krencik R, Zhang X, Ma L, Zhou GM, Ayala M, Zhang SC: Medial ganglionic eminence-like cells derived from human embryonic stem cells correct learning and memory deficits. Nat Biotechnol 2013, 31:440-447.

32. Bibel M, Richter J, Schrenk K, Tucker KL, Staiger V, Korte M, Goetz M, Barde YA: Differentiation of mouse embryonic stem cells into a defined neuronal lineage. Nat Neurosci 2004, 7:1003-1009.

33. Shi Y, Kirwan P, Livesey FJ: Directed differentiation of human pluripotent stem cells to cerebral cortex neurons and neural networks. Nat Protoc 2012, 7:1836-1846.

34. Elkabetz Y, Panagiotakos G, Al Shamy G, Socci ND, Tabar V, Studer L: Human ES cell-derived neural rosettes reveal a functionally distinct early neural stem cell stage. Genes Dev 2008, 22:152-165.
35. Kim J, Basak JM, Holtzman DM: The role of apolipoprotein E in Alzheimer's disease. Neuron 2009, 63:287-303.

36. Ooi L, Sidhu K, Poljak A, Sutherland G, O'Connor MD, Sachdev P, Munch G: Induced pluripotent stem cells as tools for disease modelling and drug discovery in Alzheimer's disease. J Neural Transm 2013, 120:103-111.

37. Schmechel DE, Saunders AM, Strittmatter WJ, Crain BJ, Hulette CM, Joo SH, Pericak-Vance MA, Goldgaber D, Roses AD: Increased amyloid betapeptide deposition in cerebral cortex as a consequence of apolipoprotein E genotype in late-onset Alzheimer disease. Proc Natl Acad Sci USA 1993, 90:9649-9653.

38. Corder EH, Saunders AM, Strittmatter WJ, Schmechel DE, Gaskell PC, Small GW, Roses AD, Haines JL, Pericak-Vance MA: Gene dose of apolipoprotein E type 4 allele and the risk of Alzheimer's disease in late onset families. Science 1993, 261:921-923.

39. Tiraboschi P, Hansen LA, Masliah E, Alford M, Thal LJ, Corey-Bloom J: Impact of APOE genotype on neuropathologic and neurochemical markers of Alzheimer disease. Neurology 2004, 62:1977-1983.

40. Bales KR, Liu F, Wu S, Lin S, Koger D, DeLong C, Hansen JC, Sullivan PM, Paul SM: Human APOE isoform-dependent effects on brain beta-amyloid levels in PDAPP transgenic mice. J Neurosci 2009, 29:6771-6779.

41. Holtzman DM, Bales KR, Tenkova T, Fagan AM, Parsadanian M, Sartorius LJ, Mackey B, Olney J, McKeel D, Wozniak D, Paul SM: Apolipoprotein E isoform-dependent amyloid deposition and neuritic degeneration in a mouse model of Alzheimer's disease. Proc Natl Acad Sci USA 2000, 97:2892-2897.

42. Liraz O, Boehm-Cagan A, Michaelson DM: ApoE4 induces Abeta42, tau, and neuronal pathology in the hippocampus of young targeted replacement apoE4 mice. Mol neurodegeneration 2013, 8:16.

43. Wyss-Coray T, Loike JD, Brionne TC, Lu E, Anankov R, Yan F, Silverstein SC, Husemann J: Adult mouse astrocytes degrade amyloid-beta in vitro and in situ. Nat Med 2003, 9:453-457.

44. Koistinaho M, Lin S, Wu X, Esterman M, Koger D, Hanson J, Higgs R, Liu F, Malkani S, Bales KR, Paul SM: Apolipoprotein E promotes astrocyte colocalization and degradation of deposited amyloid-beta peptides. Nat Med 2004, 10:719-726.

45. Metzger RE, LaDu MJ, Pan JB, Getz GS, Frail DE, Falduto MT: Neurons of the human frontal cortex display apolipoprotein $\mathrm{E}$ immunoreactivity: implications for Alzheimer's disease. J Neuropathol Exp Neurol 1996, 55:372-380.

46. Xu PT, Gilbert JR, Qiu HL, Ervin J, Rothrock-Christian TR, Hulette C, Schmechel DE: Specific regional transcription of apolipoprotein $E$ in human brain neurons. Am J Pathol 1999, 154:601-611.

47. Wolfe MS, Xia W, Moore CL, Leatherwood DD, Ostaszewski B, Rahmati T, Donkor IO, Selkoe DJ: Peptidomimetic probes and molecular modeling suggest that Alzheimer's gamma-secretase is an intramembrane-cleaving aspartyl protease. Biochemistry 1999, 38:4720-4727.

48. Moore CL, Diehl TS, Selkoe DJ, Wolfe MS: Toward the characterization and identification of gamma-secretases using transition-state analogue inhibitors. Ann N Y Acad Sci 2000, 920:197-205.

49. Siemers E, Skinner M, Dean RA, Gonzales C, Satterwhite J, Farlow M, Ness D, May PC: Safety, tolerability, and changes in amyloid beta concentrations after administration of a gamma-secretase inhibitor in volunteers. Clin Neuropharmacol 2005, 28:126-132.

50. Zhang L, Song L, Terracina G, Liu Y, Pramanik B, Parker E: Biochemical characterization of the gamma-secretase activity that produces betaamyloid peptides. Biochemistry 2001, 40:5049-5055.

51. Burton CR, Meredith JE, Barten DM, Goldstein ME, Krause CM, Kieras CJ, Sisk L, Iben LG, Polson C, Thompson MW, et al: The amyloid-beta rise and gamma-secretase inhibitor potency depend on the level of substrate expression. J Biol Chem 2008, 283:22992-23003.

52. Nicoll JA, Roberts GW, Graham DI: Amyloid beta-protein, APOE genotype and head injury. Ann N Y Acad Sci 1996, 777:271-275.

53. Slooter AJ, Tang MX, van Duijn CM, Stern Y, Ott A, Bell K, Breteler MM, Van Broeckhoven C, Tatemichi TK, Tycko B, et al: Apolipoprotein E epsilon4 and the risk of dementia with stroke. A population-based investigation. JAMA 1997, 277:818-821.

54. Lipton SA, Rosenberg PA: Excitatory amino acids as a final common pathway for neurologic disorders. N Engl J Med 1994, 330:613-622.

55. Sheng H, Laskowitz DT, Bennett E, Schmechel DE, Bart RD, Saunders AM, Pearlstein RD, Roses AD, Warner DS: Apolipoprotein E isoform-specific differences in outcome from focal ischemia in transgenic mice. J Cereb Blood Flow Metab 1998, 18:361-366. 
56. Zhang XM, Mao XJ, Zhang HL, Zheng XY, Pham T, Adem A, Winblad B, Mix E, Zhu J: Overexpression of apolipoprotein E4 increases kainic-acidinduced hippocampal neurodegeneration. Exp Neurol 2012, 233:323-332.

57. Jordan J, Galindo MF, Miller RJ, Reardon CA, Getz GS, LaDu MJ: Isoformspecific effect of apolipoprotein E on cell survival and beta-amyloidinduced toxicity in rat hippocampal pyramidal neuronal cultures. J Neurosci 1998, 18:195-204.

58. Lendon $\mathrm{CL}$, Han BH, Salimi K, Fagan AM, Behrens MI, Muller MC, Holtzman DM: No effect of apolipoprotein $E$ on neuronal cell death due to excitotoxic and apoptotic agents in vitro and neonatal hypoxic ischaemia in vivo. Eur J Neurosci 2000, 12:2235-2242

59. Buttini M, Orth M, Bellosta S, Akeefe H, Pitas RE, Wyss-Coray T, Mucke L, Mahley RW: Expression of human apolipoprotein E3 or E4 in the brains of Apoe-/- mice: isoform-specific effects on neurodegeneration. J Neurosci 1999, 19:4867-4880.

60. Buttini M, Masliah E, Yu GQ, Palop JJ, Chang S, Bernardo A, Lin C, WyssCoray T, Huang Y, Mucke L: Cellular source of apolipoprotein E4 determines neuronal susceptibility to excitotoxic injury in transgenic mice. Am J Pathol 2010, 177:563-569.

61. Wang XS, Gruenstein E: Rapid elevation of neuronal cytoplasmic calcium by apolipoprotein E peptide. J Cell Physiol 1997, 173:73-83.

62. Tolar M, Keller JN, Chan S, Mattson MP, Marques MA, Crutcher KA: Truncated apolipoprotein E (ApoE) causes increased intracellular calcium and may mediate ApoE neurotoxicity. J Neurosci 1999, 19:7100-7110.

63. Muller W, Meske V, Berlin K, Scharnagl H, Marz W, Ohm TG: Apolipoprotein $\mathrm{E}$ isoforms increase intracellular $\mathrm{Ca} 2+$ differentially through a omegaagatoxin IVa-sensitive Ca2 + -channel. Brain Pathol 1998, 8:641-653.

64. Veinbergs I, Everson A, Sagara Y, Masliah E: Neurotoxic effects of apolipoprotein $\mathrm{E} 4$ are mediated via dysregulation of calcium homeostasis. J Neurosci Res 2002, 67:379-387.

65. Sattler R, Tymianski M: Molecular mechanisms of glutamate receptormediated excitotoxic neuronal cell death. Mol Neurobiol 2001, 24:107-129.

66. Tymianski M, Charlton MP, Carlen PL, Tator CH: Source specificity of early calcium neurotoxicity in cultured embryonic spinal neurons. J Neurosci 1993, 13:2085-2104.

67. Sattler R, Charlton MP, Hafner M, Tymianski M: Distinct influx pathways, not calcium load, determine neuronal vulnerability to calcium neurotoxicity. J Neurochem 1998, 71:2349-2364.

doi:10.1186/1750-1326-9-3

Cite this article as: Duan et al: Stem cell derived basal forebrain cholinergic neurons from Alzheimer's disease patients are more susceptible to cell death. Molecular Neurodegeneration 2014 9:3.

\section{Submit your next manuscript to BioMed Central and take full advantage of:}

- Convenient online submission

- Thorough peer review

- No space constraints or color figure charges

- Immediate publication on acceptance

- Inclusion in PubMed, CAS, Scopus and Google Scholar

- Research which is freely available for redistribution

Submit your manuscript at www.biomedcentral.com/submit
C Biomed Central 